\title{
Phytochemicals and Quality of Green and Black Teas from Different Clones of Tea Plant
}

\author{
Yadav KC $\mathbb{D},{ }^{1}$ Ashok Parajuli, ${ }^{2}$ Bishnu Bahadur Khatri, ${ }^{3}$ and Lila Devi Shiwakoti $\mathbb{D}^{4}$ \\ ${ }^{1}$ Central Campus of Technology, Tribhuvan University, Dharan, Nepal \\ ${ }^{2}$ Central Department of Food Technology, Tribhuvan University, Dharan, Nepal \\ ${ }^{3}$ Central Department of Rural Development, Tribhuvan University, Kathmandu, Nepal \\ ${ }^{4}$ National Tea and Coffee Development Board, Hile, Nepal \\ Correspondence should be addressed to Yadav KC; ykcdng504@gmail.com
}

Received 24 May 2020; Revised 28 June 2020; Accepted 8 July 2020; Published 28 July 2020

Academic Editor: Seyed Mohammad Taghi Gharibzahedi

Copyright $(2020$ Yadav KC et al. This is an open access article distributed under the Creative Commons Attribution License, which permits unrestricted use, distribution, and reproduction in any medium, provided the original work is properly cited.

\begin{abstract}
Tea is a popular drink with refreshing and functional properties. Bud, $1^{\text {st }}$ leaf, and $2^{\text {nd }}$ leaf of five varieties of tea clones (Gumti Takda-78, Ambari, Chiniya, and Tinali, which are popular in tea plantation area of Nepal) were collected and used for preparing green and orthodox black tea to study antioxidant activity, phytochemicals profile, chemical content, and sensory parameters. One or two leaves were hand-plucked from each bush to get a sample of about 100 leaves and processed for green and orthodox black tea for different clones of tea plants. Phytochemicals, antioxidant activity, and caffeine content were found higher in bud followed by $1^{\text {st }}$ leaf and $2^{\text {nd }}$ leaf for all clones of tea plants. Both types of tea (green and black) from Gumti were significantly $(p<0.05)$ higher having tannin content, flavonoid content, total polyphenol content, caffeine content, and $\mathrm{IC}_{50}$ value of 49.15 and 36.23 (mg GAE/g dry extract), 358.9 and 350.4 (mg QE/g dry extract), 590.5 and 570 (mg GAE/g dry extract), 2.85 and 2.94\%, and 45.15 \& $51.88 \mu \mathrm{g} / \mathrm{mL}$, respectively. Green and orthodox tea from Takda-78 was found higher in caffeine content and the least in Tinali for both types of tea. Moisture, water extract, total ash, acid-insoluble ash, and crude fiber content in tea (green and black) from Gumti were found to be $5.4 \% \& 5.37 \%, 65.89 \% \& 71.46 \%, 5.524 \% \& 6.52 \%, 0.46 \% \& 0.57 \%$, and $7.96 \% \& 10.27 \%$, respectively. The ratio of theaflavin and thearubigin (TF: TR) was found $1: 8.61,1: 9.36,1: 9.70,1: 12.87$, and $1: 6.36$ in Takda-78, Ambari, Gumti, Chiniya, and Tinali respectively. The total quality score in green tea $(85.13 \%)$ and black tea $(85.78 \%)$ from Gumti was significantly higher than others. Phytochemicals and antioxidant properties of green tea were significantly $(p<0.05)$ higher than those of orthodox black tea for all clones of tea plant. This study suggests Gumti variety to be used in green and orthodox black tea processing for higher phytochemical, chemical, sensory quality, and antioxidant activity.
\end{abstract}

\section{Introduction}

Tea plant (Camellia sinensis L.) is a source of tea brew which is a very refreshing and popular drink in the world that is defined as the hot aqueous infusion of dried leaves. It is the extract of leaves, leaf nodes, and internodes of the plant (Camellia sinensis L.) [1]. Three types of tea (nonfermented, semifermented, and fermented) are categorized based on the degree of fermentation, whose examples are green tea, oolong tea, and black tea, respectively [2]. They have not only the stimulating effect but also therapeutic properties because of polyphenolic compounds present in them. It is reported that tea contains nearly 4000 bioactive compounds while polyphenols contribute to $33 \%$ and catechins are the predominantly present polyphenols. Other chemical constituents like alkaloids, amino acids, carbohydrates, proteins, chlorophyll, volatile organic compounds, and trace elements are also present [3]. The composition and quality of tea can be affected by several parameters associated with growth conditions and manufacturing processes which are also influencing factors in the profile of bioactive compounds. Soil profile, season and climatic conditions, growth altitude, horticultural practices, plucking season, shade growth, and genetic variations are parameters of growth conditions while withering, steaming or pan-firing, rolling, fermentation, drying storage, and packaging are parameters of the 
manufacturing process [4]. Green tea was found to have higher concentrations of phenolic compounds and the major antioxidant activities than black tea [5]. Tea of Nepal has its own value and fame in the world because of its fine subtle and pleasant fruity flavor and good quality. This is due to cool climate, elevation, soil, and the environment of tea growing areas. The unique art of processing tea with utmost care is one of the parts for its pristine quality. There is still lacking sufficient evidence of researches on chemical profiling of the leaves and tea type from different clones of the tea plant in Nepal. Thus, this research is focused on chemical profiling of tea leaves and analyzing antioxidant activity, phytochemicals profile, chemical content, and sensory parameters of tea types from different tea clones.

\section{Materials and Methods}

2.1. Collection of Tea Leaves. Tea leaves (bud, $1^{\text {st }}$ leaf, and $2^{\text {nd }}$ leaf) of Chinese varieties (Chiniya, Takda-78, Tinali Ambari, and Gumti) were collected manually by hand plucking. One or two leaves were plucked from each bush to get a sample of about 100 leaves. Different places of Suryodaya Municipality, Ilam, were used to collect the samples. Ambari and Chiniya were collected from Kattebung $\left(26^{\circ} 55^{\prime} 26.25^{\prime \prime} \mathrm{N}\right.$, $88^{\circ}$ $06^{\prime} 03.82^{\prime \prime}$ E, elevation $\left.1635 \mathrm{~m}\right)$, Tinali from Kattebung $\left(26^{\circ}\right.$ $55^{\prime} 20.32^{\prime \prime} \mathrm{N}, 88^{\circ} 05^{\prime} 51.19^{\prime \prime} \mathrm{E}$ and elevation $1581 \mathrm{~m}$ ), Gumti from Jarayotar $\left(26^{\circ} 56^{\prime} 41.71^{\prime \prime} \mathrm{N}, 88^{\circ} 06^{\prime} 09.92^{\prime \prime}\right.$ E elevation $1874 \mathrm{~m}$ ), and Takda-78 from Aarthetar $\left(26^{\circ} 56^{\prime} 05.87^{\prime \prime} \mathrm{N}, 88^{\circ}\right.$ $07^{\prime} 14.69^{\prime \prime} \mathrm{E}$ and elevation $1715 \mathrm{~m}$ ) in the $1^{\text {st }}$ week of April 2019 (first flush) and processed for green and orthodox black tea. Buds from different tea clones were coded as $A B, C B$, GB, TB, and T78-B for Ambari, Chiniya, Gumti, Tinali, and Takda-78, respectively. The first leaf and second leaf were coded as A1 and A2, C1 and C2, G1 and G2, T1 and T2, and T78-1 and T78-2 for Ambari, Chiniya, Gumti, Tinali, and Takda-78, respectively.

2.2. Preparation of Green and Orthodox Black Tea. Green and orthodox black tea was prepared from each variety separately. The process variables were selected as per the findings of various researches like [6-8], with slight modifications based on local climate and practices as presented in Figure 1. Green tea from Ambari, Chiniya, Gumti, Tinali, and Takda78 was coded as $A-g, C-g, G-g, T-g$, and $T 78-g$, respectively. Black tea was coded as $A-b, C-b, G-b, T-b$, and T78- $b$ for Ambari, Chiniya, Gumti, Tinali, and Takda-78, respectively.

2.3. Chemicals and Reagents. Analytical grade reagents from different suppliers were used for all experiments. Hydrochloric acid (assay: $>35 \%$ (concentrated), Emplura ${ }^{\circledR}$ ), methanol (assay: $>99 \%$, Emplura ${ }^{\circledR}$ ), Folin-Ciocalteu reagent (A.R. grade, Fisher Scientific, India), sodium carbonate (assay: 99.5\%, Fizmerk India Chemicals), gallic acid (assay: 99.5\%, Loba Chemie, India), aluminum chloride (assay: 98.5\%, Qualigens, India), sodium nitrite (assay: $>98 \%$, Merck Specialties Pvt. Ltd.), sodium hydroxide (assay: 98\%, Qualigens, India), quercetin (assay: $b>98 \%$, Himedia, India), 2,2-diphenyl-1-picrylhydrazyl (DPPH) (assay: 95\%,
Sisco Research Laboratories. Pvt. Ltd., India), dichloromethane (assay: $>99.5 \%$, Himedia, India), di-sodium phosphate (assay: $>99 \%$, Himedia, India), oxalic acid dihydrate (assay: $\geq 99.0 \%$, Emplura ${ }^{\circledR}$ ), ethyl acetate (assay: $>99.5 \%$, Himedia, India), and caffeine anhydrous (M.W. $194.19 \mathrm{~g} / \mathrm{mol}$, Sisco Research Laboratories. Pvt. Ltd, India) were used.

2.4. Preparation of Tea Infusion. Aqueous tea infusion was made following the method prescribed by [9] with slight modification. Five grams of tea leaves was added to $95 \mathrm{~mL}$ of distilled water and heated at $90^{\circ} \mathrm{C}$ for $10 \mathrm{~min}$ with constant stirring. Whatman no. 41 filter paper was used instantly to filter brewed teas to remove suspended particles and tea infusions were stored in the refrigerator (IIC- 181, accuracy $\pm 0.5^{\circ} \mathrm{C}$, SIMA Labs Pvt. Ltd., India) at $4^{\circ} \mathrm{C}$ after cooling to room temperature.

\subsection{Physicochemical Analysis}

2.5.1. Water Extract. The international standard method (ISO-9768) was used to determine water extract. In brief, $50 \mathrm{~mL}$ tea extract was prepared as described in Section 2.4 and evaporated in a dish on a boiling water bath to rough dry mass. Until complete dryness, it was further dried in a hot air oven (RDHO 50, accuracy $\pm 1^{\circ} \mathrm{C}$, Remi Elektrotechnik Limited, India) at $103^{\circ} \mathrm{C}$. Then, it was cooled down to room temperature in a silica-gel desiccator and weighed in digital balance (NLB-1204, capacity 120 g, accuracy \pm 0.001 , Phoenix, India) [10].

2.5.2. Total Ash. Five grams of sample was taken into a dried and weighed silica crucible. The crucible and its content were ignited on a Bunsen burner. Then, dry ashing was done at $525^{\circ} \mathrm{C}$ for $4 \mathrm{~h}$. The crucible was cooled and weighed [11].

2.5.3. Acid-Insoluble Ash. The ash in the silica crucible from dry ashing was boiled with $25 \mathrm{~mL}$ of dilute $\mathrm{HCl}(10 \% \mathrm{w} / \mathrm{w})$ over a low flame for $5 \mathrm{~min}$. It was filtered hot through an ashless filter paper and washed thoroughly with hot water. The filter paper was returned to the original crucible, ignited in a muffle furnace (max. $1200^{\circ} \mathrm{C}$, Suntech Enterprise, India), cooled, and weighed as acid-insoluble ash [11].

2.5.4. Determination of Crude Fiber. The crude fiber was determined by standard AOAC methods [12].

2.5.5. Determination of Moisture Content. The moisture content in the samples was determined by standard AOAC methods [12].

2.6. Extraction of Phytochemicals. Phytochemicals from prepared tea and leaves (bud, $1^{\text {st }}$ leaf, and $2^{\text {nd }}$ leaf)) were extracted using methanol [13] with slight modification. Ten grams of samples was steeped in $100 \mathrm{~mL}$ of $80 \%$ methanol at $65^{\circ} \mathrm{C}$ for $10 \mathrm{~min}$. Then, it was cooled to room temperature 

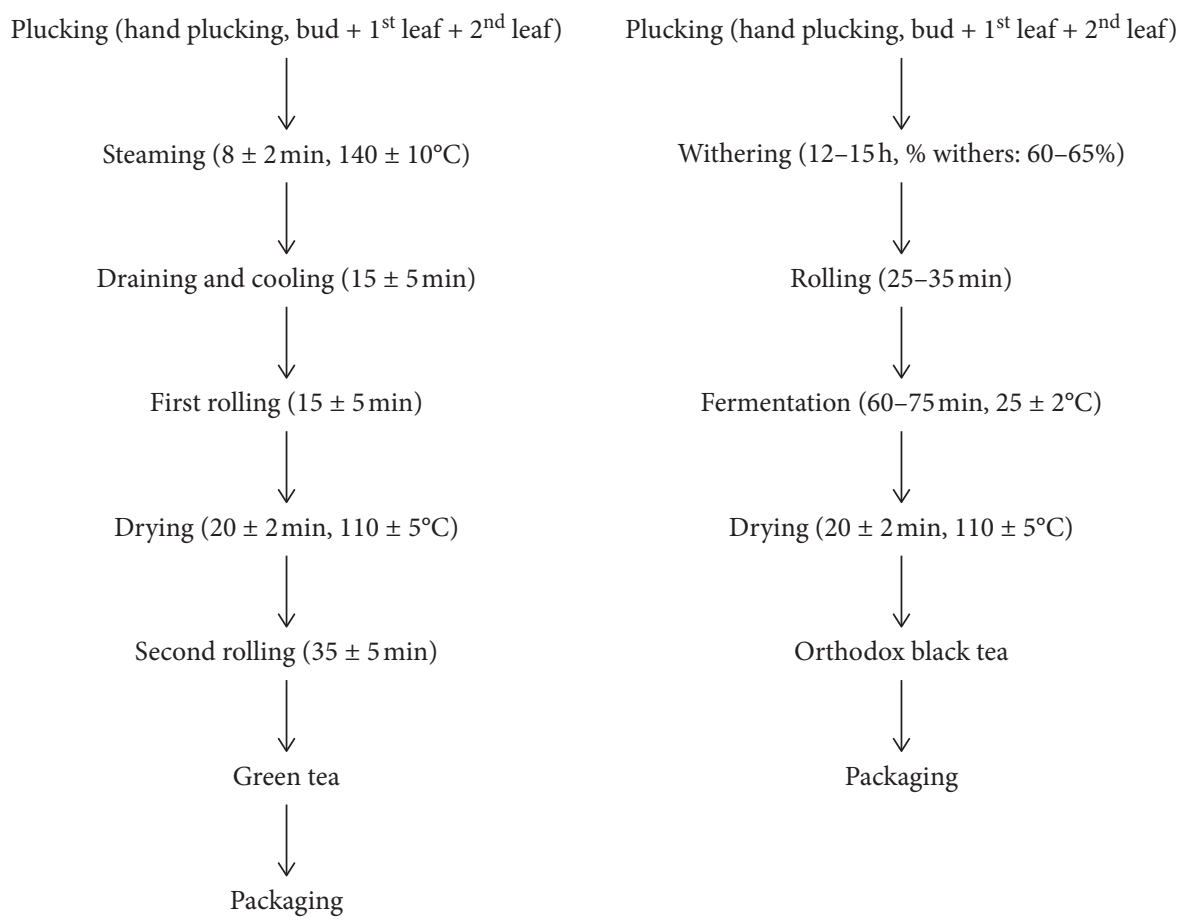

Fermentation $\left(60-75 \min , 25 \pm 2^{\circ} \mathrm{C}\right)$
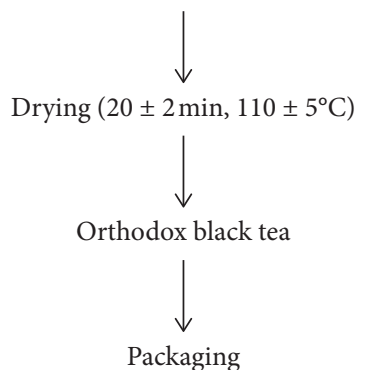

Figure 1: Flow chart illustrating the processes in preparation of (a) green tea and (b) orthodox black tea.

and homogenized for 3 min using a grinder (MG 3053, Usha, India). Subsequently, it was filtered using Whatman no. 41 and the residue was reextracted following the above procedure. The extract was stored in a screw-capped bottle at $4 \pm 2{ }^{\circ} \mathrm{C}$ until analysis. Ten $\mathrm{mL}$ of extract was evaporated, dried at $80^{\circ} \mathrm{C}$, and the residue was weighed to know its concentration.

2.6.1. Determination of Total Phenolic Content (TPC). TPC of the sample was determined using the spectrophotometric method [14] with some modifications. In brief, $0.5 \mathrm{~mL}$ of methanolic extract, $2.5 \mathrm{~mL}$ of $10 \%$ Folin-Ciocalteu's reagent, and $2.5 \mathrm{~mL}$ of $7.5 \%$ of $\mathrm{Na}_{2} \mathrm{CO}_{3}$ were mixed and incubated in an incubator (accuracy $\pm 1^{\circ} \mathrm{C}, \mathrm{MYQ}$ engineering Pvt. Ltd) at $45^{\circ} \mathrm{C}$ for $45 \mathrm{~min}$. The absorbance at $765 \mathrm{~nm}$ on UVVis spectrophotometer (LT-2203, wavelength range 190-1100 nm, Labtronics, India) for each sample was analyzed in triplicate. The test results were correlated with the standard gallic acid curve, and TPC was expressed as mg gallic acid equivalent (mg GAE/g) of dry extract.

2.6.2. Determination of Total Flavonoid Content (TFC). TFC of the sample was determined using a modified aluminum chloride assay method [15]. Two $\mathrm{mL}$ of methanolic extract was mixed with $0.2 \mathrm{~mL}$ of $\mathrm{NaNO}_{2}(5 \%, \mathrm{w} / \mathrm{v})$, and after $5 \mathrm{~min}, 0.2 \mathrm{~mL}$ of $\mathrm{AlCl}_{3}(2 \%$, w/v) was added and allowed to stand for $6 \mathrm{~min}$. This followed the addition of $2 \mathrm{~mL}$ of $1 \mathrm{~N}$ $\mathrm{NaOH}$, and finally, the volume was made up to $5 \mathrm{~mL}$. After holding for $15 \mathrm{~min}$ at room temperature, the absorbance was measured at $510 \mathrm{~nm}$ on the UV-Vis spectrophotometer. The test result was correlated with the standard quercetin curve, and TFC was expressed as mg quercetin equivalents (mg QE/g) of dry extract.
2.6.3. Determination of Tannin Content. The tannin content in the samples was determined by the Folin-Ciocalteu method [16]. In brief, $0.1 \mathrm{~mL}$ of methanolic extract was added to the volumetric flask that contained $7.5 \mathrm{~mL}$ distilled water, $0.5 \mathrm{~mL}$ Folin-Ciocalteu reagent, and $1 \mathrm{~mL} 35 \%$ $\mathrm{Na}_{2} \mathrm{CO}_{3}$ solution. Then, the volume of the mixture solution was made up to $10 \mathrm{~mL}$ with distilled water and shaken well. After holding for $30 \mathrm{~min}$ at room temperature, the absorbance was measured at $725 \mathrm{~nm}$ on UV/visible. The test results were correlated with the standard gallic acid curve, and tannin content was expressed as mg gallic acid equivalent (mg GAE/g) of dry extract.

2.6.4. Determination of DPPH Radical Scavenging Activity. The DPPH radical scavenging activities (antioxidant activities) of the extracts were determined by the spectrophotometric method [17]. One mL of the extract was mixed with $2 \mathrm{~mL}$ of DPPH $(0.004 \%$ in methanol, corresponding to $100 \mu \mathrm{M}$ ) incubated at $37^{\circ} \mathrm{C}$ in dark (wrapped with aluminum foil) for $20 \mathrm{~min}$ (for completion of reaction) before spectrophotometric analysis. The absorbance was measured at $517 \mathrm{~nm}$ on the UV-Vis spectrophotometer after $30 \mathrm{~min}$ incubation in the dark. Finally, the percentage scavenging activity was determined using the following equation:

$$
\text { scavenging activity }(\%)=\frac{A_{\mathrm{c}}-A_{\mathrm{s}}}{A_{\mathrm{c}}} \times 100 \text {, }
$$

where $A_{\mathrm{c}}$ represents the absorbance of the control, and $A_{\mathrm{s}}$ stands for absorbance of the test sample. The $\mathrm{IC}_{50}$ was determined as the concentration required to give $50 \%$ scavenging activity using the linear regression equation. 
2.7. Determination of Caffeine Content. The caffeine content in the samples was determined by UV-Vis spectrophotometric method $[18,19]$ with slight modifications. In brief, $2.5 \mathrm{~g}$ of tea and tea leaf samples each was poured to $200 \mathrm{~mL}$ of boiling water and stirred for 10 minutes. After filtering through cotton wool, the extract was cooled at room temperature and the volume was made to $250 \mathrm{~mL}$ with distilled water. This solution was mixed with dichloromethane in ratio $1: 1(25: 25 \mathrm{~mL})$ for the extraction of caffeine from tea samples. It was stirred for $10 \mathrm{~min}$ and caffeine was extracted by dichloromethane from the solution with the help of separating funnel $(25 \mathrm{~mL}$ to $5 \mathrm{~L}$, Sabar Scientific, India). Caffeine was extracted 4 times with $25 \mathrm{~mL}$ dichloromethane at each round and was stored in volumetric flasks. The absorbance of the extracted solution was measured at $270 \mathrm{~nm}$ on the UV/visible spectrophotometer. The test results were correlated with the standard calibration curve of the caffeine curve and it was expressed in percentage (\%).

2.8. Analysis of Theaflavin (TF), Thearubigin (TR), Color, and Brightness. TF, TR, color, and brightness were determined by the spectrophotometric method [20]. Tea infusion was prepared by boiling $9 \mathrm{~g}$ sample with $375 \mathrm{~mL}$ water continuously for $10 \mathrm{~min}$ in a conical flask. After filtering the tea infusion through a cotton cloth, it was cooled to room temperature. Six $\mathrm{mL}$ infusion and $6 \mathrm{~mL}$ of $1 \%(\mathrm{w} / \mathrm{v})$ aqueous solution of $\mathrm{Na}_{2} \mathrm{HPO}_{4}$ were mixed, and the mixture solution was extracted with $10 \mathrm{~mL}$ of ethyl acetate by quickly repeated inversion for $1 \mathrm{~min}$. After draining out the separated bottom layer, the TF fraction (ethyl acetate layer) was diluted with $5 \mathrm{~mL}$ ethyl acetate. Optical densities (E1, E2, and E3) obtained for the extracts were measured at 380 and $460 \mathrm{~nm}$ on a $\mathrm{UV} /$ visible spectrophotometer.

$E 1$ is the TF extract $(10 \mathrm{~mL})$ diluted to $25 \mathrm{~mL}$ with methanol; E2 is the infusion $(1 \mathrm{~mL})$ diluted to $10 \mathrm{~mL}$ with water and made up to $25 \mathrm{~mL}$ with methanol; $E 3$ is the infusion $(1 \mathrm{~mL})$ mixed with aqueous oxalic acid $(10 \% \mathrm{w} / \mathrm{v}, 1 \mathrm{~mL})$ and water $(8 \mathrm{~mL})$ and made up to $25 \mathrm{~mL}$ with methanol.

Percent TF and percent TR were calculated at $380 \mathrm{~nm}$ while at $460 \mathrm{~nm}$ the total color and percent brightness were calculated as follows:

$$
\begin{aligned}
\operatorname{TF}(\%) & =2.25 \times E 1, \\
\operatorname{TR}(\%) & =7.06 \times(4 E 3-E 1), \\
\text { total color } & =6.25 \times 4 E 2, \\
\text { brightness }(\%) & =\frac{E 1}{4 E 2} \times 100 .
\end{aligned}
$$

2.9. Sensory Evaluation (Cup Tasting) of Tea. Cup tasting of the tea (black and green) was evaluated by twelve panelists [21] on the basis of a maximum total quality score of 100 . Sensory parameters were analyzed with a quality score of $10 \%, 30 \%, 15 \%, 35 \%$, and $10 \%$ for dry tea appearance, aroma, brew color, taste, and infused leaves, respectively. A $2 \mathrm{~h}$ training session was conducted for 4 days to familiarize panel members with sensory attributes. Three grams of samples was added in $150 \mathrm{~mL}$ boiled water for $5 \mathrm{~min}$ and served to panelists with proper arrangements and code to analyze the sensory attributes [22].

2.10. Statistical Analysis. The data of each experimental analysis that was performed in triplicate was analyzed by oneway analysis of variance (ANOVA) and $t$-test by using software GenStat Release 12.1 (Copyright 2009, VSN International Ltd.). MS-Excel 2010 was used for charts and curves. Means were separated using Tukey's HSD post hoc test $(p<0.05)$.

\section{Results and Discussion}

3.1. Characteristics of Tea Leaves on Different Clones. Tannin content decreased significantly $(p<0.05)$ from bud to the second leaf for all varieties of tea plants (Figure 2(a)). The tannin content in young shoots of 3 different cultivars was found to have variable results [23]. Ambari varieties were found to have higher tannin content and Chiniya variety with the least (Figure 2(a)). Variation of tannin content in tea due to variation of the place of origin was reported in different studies. Flavonoid content decreased significantly $(p<0.05)$ by 3 to $12.8 \%$ from bud to the second leaf (Figure 2(a)). A similar result was obtained in Sabah Tea Plantation Sabah, Malaysia [24]. The percentage of total polyphenols in various tea leaf positions tended to decrease by $3.11 \%$ in Takda-78 to $6.11 \%$ in Ambari from bud to the second leaf (Figure 2(a)). Similar results were obtained in the study of old tea leaves and young tea leaves in the southern part of China [25] and in the study of tea at different stages of leaf maturity at Research Institute for Tea and Cinchona, Java [26]. Total phenolics in this study were extracted with methanol which is soluble in it. During the maturity of the leaves, the biosynthesis pathways get diverted from soluble phenolics towards lignins and condensed tannin causing lower values of soluble phenolics [25]. Lower values of TPC might be due to the transportation of chemical compounds within the plant and changes in morphological characteristics of the leaf with maturity [27]. Caffeine content decreased significantly with an increase in the maturity of the leaf in all varieties of tea plants (Figure 2(b)). Buds and young leaves are higher in caffeine than mature leaves [4] which might be due to caffeine being a natural insecticide and used mostly to protect younger leaves before older ones. Percent DPPH radical scavenging activity (RSA) is better expressed as $\mathrm{IC}_{50}$ (the inhibition concentration of sample extract needed to reduce initial DPPH activity by 50\%). The lower the $\mathrm{IC}_{50}$ value, the stronger the RSA in the sample [28]. RSA in the tea leaves ranged from $55.89 \%$ in T2 to $91.29 \%$ in $\mathrm{GB}$ and $\mathrm{IC}_{50}$ in the leaves ranged from 21.99 in GB to 76.32 $(\mu \mathrm{g} / \mathrm{mL})$ in T2 (Figure 2(c)). RSA was in the order bud $>$ Ist leaf $>2$ nd leaf (for all varieties). Similarly, $\mathrm{IC}_{50}$ was in the order $2^{\text {nd }}$ leaf $>1^{\text {st }}$ leaf $>$ bud (for all varieties). The antioxidant activity (AOA) of the extracts can be assessed by employing DPPH free radical scavenging method [29], and the result showed that AOA decreased significantly with an increase in the maturity of the leaf in all varieties of tea plants 


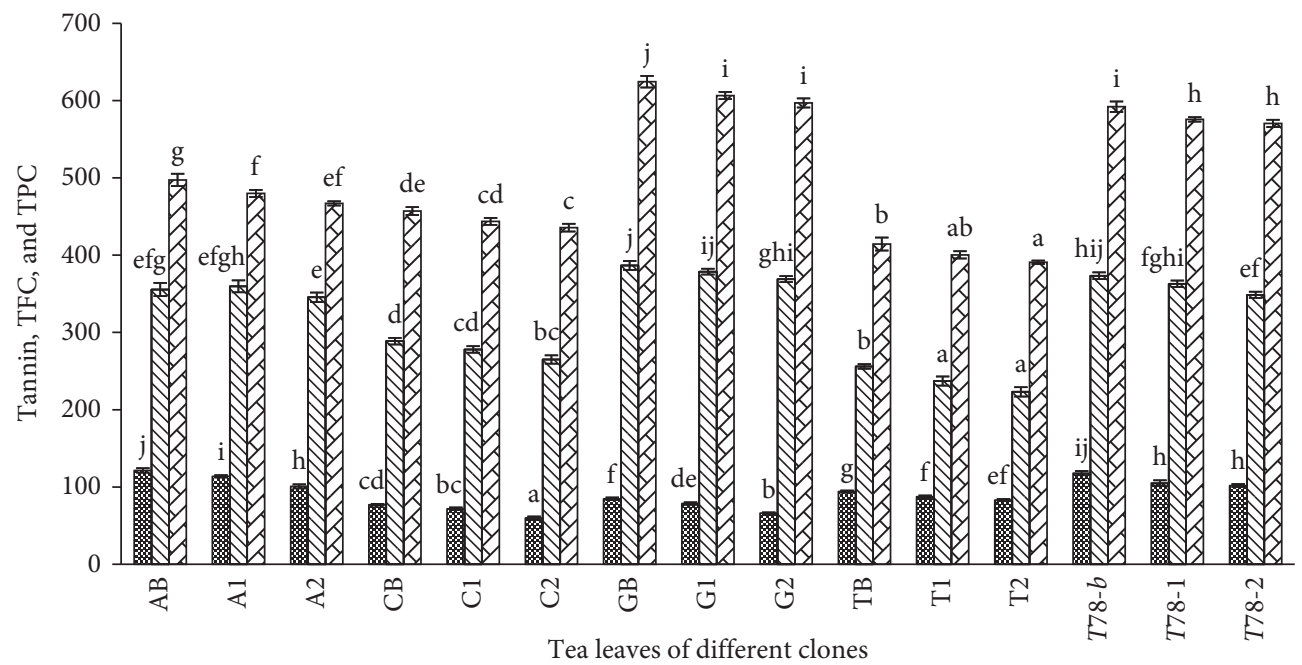

즘 Tannin (mg GAE/g dry extract)

$\checkmark$ TFC (mg QE/g dry extract)

$\square \mathrm{TPC}$ (mg GAE/g dry extract)

(a)

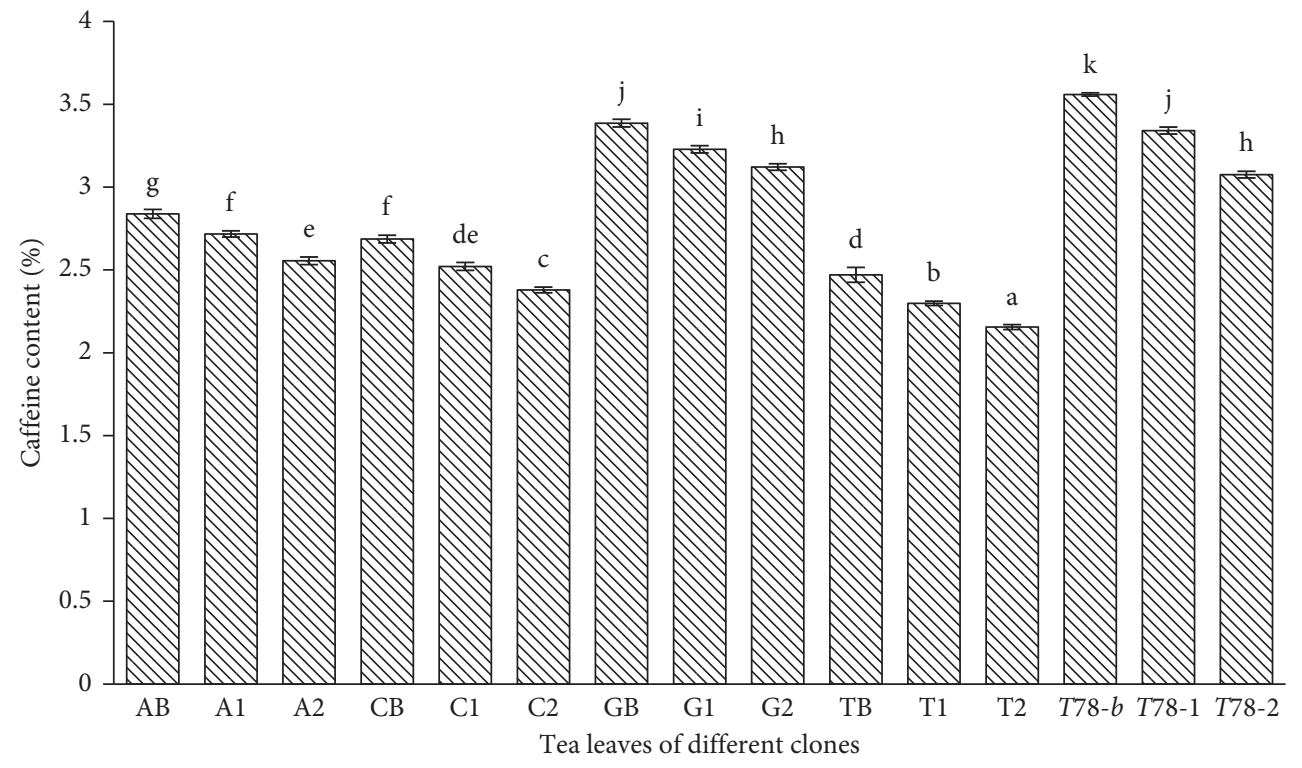

(b)

Figure 2: Continued. 


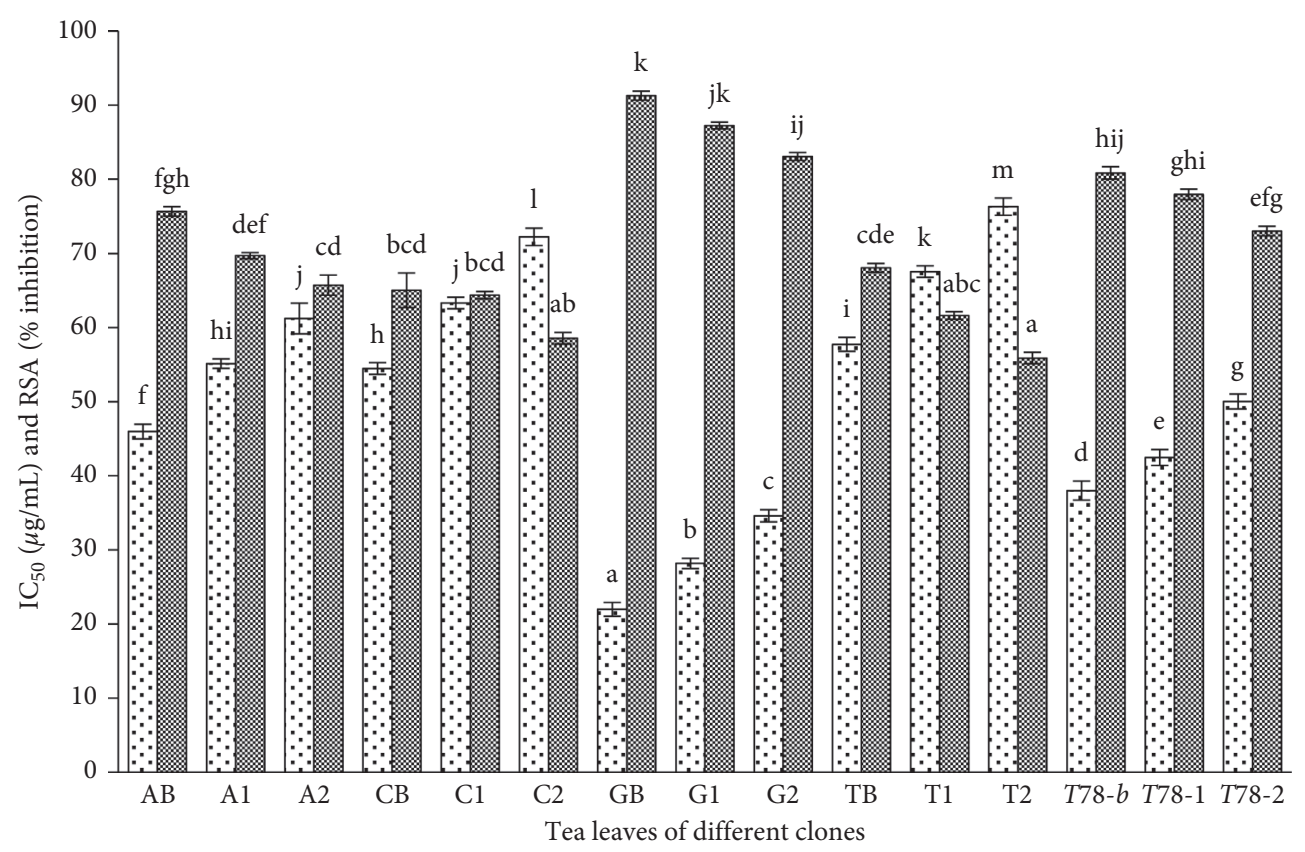

$-1 \mathrm{IC}_{50}(\mu \mathrm{g} / \mathrm{ml})$
RSA $(\% \mathrm{DPPH}$ inhibition $)$

(c)

Figure 2: Chemical characteristics of various clones of tea plant at different stages of leaf position: (a) tannin content, total phenol content, and total flavonoid content, (b) caffeine content, and (c) $\mathrm{IC}_{50}$ and RSA (\% DPPH inhibition). Error bars show standard deviation, and error bars bearing different superscripts are different $(p<0.05)$ with one-way ANOVA, and QE, GAE, RSA refer to quercetin equivalent, gallic acid equivalent, and radicle scavenging activity, respectively.

(Figure 2(c)). $\mathrm{IC}_{50}$ concentration for RSA showed a strong negative correlation $\left(R^{2}=0.8621\right)$ with total phenol content which reveals that younger leaves had more polyphenol and higher RSA (Figure 3). Similar results were revealed in the Malaysian Plantation sites [24] which might be due to a decrease in total phenols in matured leaves.

3.2. Chemical Content of Tea Type from Different Clones. Moisture content, water extract, crude fiber, total ash, and acid-insoluble ash in green and black tea are presented in Tables 1 and 2, respectively. Moisture content in the bud of each variety had no significant difference and ranged from 77.2 to $77.5 \%$ while the moisture content in the $1^{\text {st }}$ leaf of each variety ranged from 74.2 to $75.3 \%$. Similarly, the moisture content of the $2^{\text {nd }}$ leaf ranged from 69.2 to $70.8 \%$ that was similar to the study of the National Tea Research Institute, Pakistan [30]. The moisture content in the green tea and black tea of each variety (below 5.4\%) was not significantly different. It was suggested that the moisture content of the tea should be less than $6.5 \%$ for marketing purposes [31]. It was observed that black tea from the respective varieties had higher water extract than green tea. This difference among the varieties and the difference in green and black tea of respective varieties were not unexpected due to the genetic variations and manufacturing conditions which leads to the decomposition of tea components to different degrees [32]. Though water extracts for both green and black teas did not infringe the ISO standards and Nepal standards, they have higher values. The total ash was not significantly different in green tea from all varieties of tea plants. Acid-insoluble ash ranged from $0.46 \%$ in $C-g$ to $0.7 \%$ in $T-g$ for green tea while $0.46 \%$ in $C-b$ to $0.84 \%$ in $T-b$ for black. The total ash content in tea correlates with the mineral content of the tea sample and also measures the physiological ash, which is derived from the plant tissue itself [33]. The composition of the ash of tea varies somewhat with the age of the leaf because the water-soluble potash and phosphoric acid diminish as the leaves become mature [34]. The acid-insoluble ash content in tea determines contamination during the manufacturing process [33], and in all samples, it was below $1 \%$. The crude fiber in tea is an indication of the quality of starting leaf material. The genetic nature of the tea clones might be the reason for the difference among the varieties and the difference in black tea and green tea of respective varieties. Though the bud $+1^{\text {st }}$ leaf $+2^{\text {nd }}$ leaf are used in preparing both green and orthodox black tea, younger plucking in preparing green tea for all varieties might have been done. Similarly, among all varieties of tea plants, Chiniya variety had less fiber content which might be due to genetic variations [33]. The total ash, acid-insoluble ash, and crude fiber for green tea from all varieties were under the ISO 11287 and black tea under the ISO 3720 standards. Green tea from all varieties resembles Nepal standards for total ash (4-8\%), acid-insoluble ash (maximum $1 \%$ ), and crude fiber (maximum 16\%). Similarly, black 


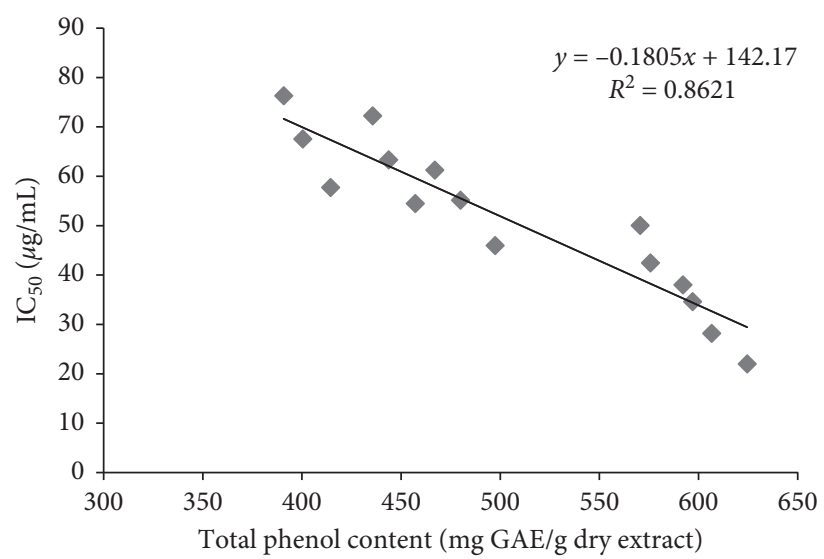

FIgURE 3: Correlation between total phenol content and $\mathrm{IC}_{50}$ concentration of the tea extract.

tea from all varieties resembles Nepal standards for total ash (5.5-8\%), acid-insoluble ash (maximum 1\%), and crude fiber (maximum 15\%) but the crude fiber in $T-b$ was found to be $15.47 \%$ which might be due to genetic variation [35].

\subsection{Phytochemical and Antioxidant Activity of Tea Type from} Different Clones. The tannin content in green and black tea of all varieties was significantly different (Figure 4(a)). Both green and black tea of Ambari variety had higher tannins which are similar to leaves. Gumti variety had significantly lower tannin in both green and black tea which might be due to genetic variation. The tannin content in green tea was significantly $(p<0.05)$ higher than that of black tea from the respective varieties of plants (Figure 4(a), Table 3 ). This might be due to the degradation of hydrolyzable tannins in black tea. Similar results were observed in white, green, and black tea extracts [36]. Both green and black tea of Gumti variety had significantly $(p<0.05)$ higher tannins which are similar to leaves. Tinali variety had significantly lower tannin in both green and black tea (Figure 4(a)). Like tannin content, flavonoid content in green tea was found significantly $(p<0.05)$ higher than that of the black tea from the respective varieties of plants (Figure 4(b), Table 3) which might be due to the participation of flavonoids during fermentation in preparing black tea. Similar results were observed in black and green tea in the research in South Africa [37]. The higher flavonoid $(232.84 \pm 0.07 \mathrm{mgQE} / \mathrm{g})$ was determined in the black tea infusions prepared at $90^{\circ} \mathrm{C}$ for $5 \mathrm{~min}$ [38] but it was found higher in all green and black tea which might be due to more leaching effect as brew was prepared at $90^{\circ} \mathrm{C}$ for $10 \mathrm{~min}$. Green and black tea from Tinali had significantly lower flavonoid content where Gumti contributed to significantly higher flavonoid in both green and black tea (Figure 4(b)). The total phenol content in green tea was significantly $(p<0.05)$ higher than that of the black tea from the respective varieties of plants (Figure 4(c), Table 3 ). There is a fermentation process in black tea so that TPC might have decreased due to the formation of polymeric tannins from monomeric phenols and the reduction of flavonol glycosides. It was stated that the reduction of total soluble phenols during tea fermentation process had a positive correlation with the reduction rate of epicatechin (EC), epigallocatechin (EGC), catechin gallate (CG), gallocatechin gallate (GCG), and total flavonol glycoside [9]. Both green and black tea of Gumti variety had significantly $(p<0.05)$ higher TPC where Tinali contributed to lower TPC in its respective green and black tea (Figure 4(c)). Polyphenols in tea can vary due to leaf handling and a variety of clones [26]. Polyphenols have been reported to have antioxidant activity and may contribute color and astringent taste of tea. G-g had higher RSA representing higher antioxidant activity (Figure 4(e)) and higher value of color and taste (Table 4). Similarly, $G-b$ had a higher value of RSA (Figure 4(e)) and a higher value of color and taste (Table 5). These parameters also support the higher value of TPC in black and green tea of Gumti variety. The caffeine content in black tea was found significantly $(p<0.05)$ higher than that of the green tea from the respective varieties of plants (Figure 4(d), Table 3), because withering and full fermentation of caffeine content might be more in black tea. Caffeine content was significantly affected by withering and fermentation [32]. The caffeine content in green tea ranged from $1.23 \%$ in $T-g$ to $3.03 \%$ in $T 78-g$ Similarly, in black tea, it ranged from $1.36 \%$ in $T-b$ to 3.11 in T78- $b$ Figure 4 (d). The caffeine content in black and green tea from all varieties resembles Nepal standard (not less than $2 \%$ ) except $T-b$ and $T-g$. There was a significant difference $(p<0.05)$ in green tea and black tea of all varieties of tea plants with respect to RSA and $\mathrm{IC}_{50}$ (Figures 4(e) and 4(f), Table 3). Epigallocatechin gallate (EGCG) and epigallocatechin (EGC) contents are quite higher in green tea than those in black tea. Three adjacent hydroxyl $(\mathrm{OH})$ groups on the B-ring of EGCG and EGC might have been more effective in scavenging free radicals than the two adjacent $\mathrm{OH}$ groups as in epicatechin gallate (ECG), catechin gallate (CG), and epicatechin (EC) [39]. Higher TPC and free radical scavenging activity were reported in green tea. Green tea was found to have higher concentrations of phenolic compounds and the major antioxidant activities than black tea [5]. During fermentation in black tea, conversion of catechins to theaflavin and thearubigin leads in the reduction of polyphenolic 
TABLE 1: Moisture content, water extract, total ash, acid-insoluble ash, and the crude fiber content of green tea prepared from different clones of the tea plant.

\begin{tabular}{|c|c|c|c|c|c|}
\hline Samples & Moisture content (\%) & Water extract (\%) & Total ash (\%) & Acid-insoluble ash (\%) & Crude fiber (\%) \\
\hline Ambari $(A-g)$ & $5.4 \pm 0.25^{\mathrm{a}}$ & $52.16 \pm 4.44^{\mathrm{a}}$ & $5.516 \pm 0.33^{\mathrm{a}}$ & $0.47 \pm 0.01^{\mathrm{b}}$ & $9.39 \pm 0.71^{\mathrm{bc}}$ \\
\hline Chiniya $(C-g)$ & $5.3 \pm 0.4^{\mathrm{a}}$ & $44.36 \pm 3.32^{\mathrm{a}}$ & $5.25 \pm 0.45^{\mathrm{a}}$ & $0.36 \pm 0.08^{\mathrm{a}}$ & $6.73 \pm 0.43^{\mathrm{a}}$ \\
\hline Gumti (G-g) & $5.4 \pm 0.3^{\mathrm{a}}$ & $65.89 \pm 2.33^{\mathrm{b}}$ & $5.524 \pm 0.12^{\mathrm{a}}$ & $0.46 \pm 0.07^{\mathrm{b}}$ & $7.96 \pm 0.80^{\mathrm{ab}}$ \\
\hline Takda-78 (T78-g) & $5.35 \pm 0.35^{\mathrm{a}}$ & $60.83 \pm 2.435^{\mathrm{b}}$ & $5.702 \pm 0.19^{\mathrm{a}}$ & $0.63 \pm 0.01^{\mathrm{c}}$ & $9.92 \pm 0.73^{c}$ \\
\hline Tinali $(T-g)$ & $5.38 \pm 0.3^{\mathrm{a}}$ & $45.22 \pm 2.59^{\mathrm{a}}$ & $5.135 \pm 0.12^{\mathrm{a}}$ & $0.70 \pm 0.07^{\mathrm{d}}$ & $12.97 \pm 0.73^{\mathrm{d}}$ \\
\hline
\end{tabular}

Values are means of triplicate \pm standard deviations. Values in the columns bearing the different superscripts are significantly different $(p<0.05)$.

TABLE 2: Moisture content, water extract, total ash, acid-insoluble ash, and the fiber content of black tea prepared from different clones of tea plants.

\begin{tabular}{|c|c|c|c|c|c|}
\hline Samples & Moisture content (\%) & Water extract (\%) & Total ash (\%) & Acid-insoluble ash (\%) & Crude fiber (\%) \\
\hline Ambari $(A-b)$ & $5.35 \pm 0.15^{\mathrm{a}}$ & $56.89 \pm 2.27^{\mathrm{ab}}$ & $6.33 \pm 0.51^{\mathrm{a}}$ & $0.62 \pm 0.51^{\mathrm{b}}$ & $13.04 \pm 0.34^{\mathrm{c}}$ \\
\hline Chiniya $(C-b)$ & $5.32 \pm 0.42^{\mathrm{a}}$ & $51.25 \pm 0.99^{\mathrm{a}}$ & $6.24 \pm 0.63^{\mathrm{a}}$ & $0.46 \pm 0.03^{\mathrm{a}}$ & $8.82 \pm 0.09^{\mathrm{a}}$ \\
\hline Gumti (G-b) & $5.37 \pm 0.28^{\mathrm{a}}$ & $71.46 \pm 2.88^{c}$ & $6.52 \pm 0.37^{\mathrm{ab}}$ & $0.57 \pm 0.03^{\mathrm{b}}$ & $10.27 \pm 0.1^{\mathrm{b}}$ \\
\hline Takda-78 (T78-b) & $5.39 \pm 0.4^{\mathrm{a}}$ & $64.09 \pm 4.04^{\mathrm{bc}}$ & $7.53 \pm 0.26^{\mathrm{b}}$ & $0.75 \pm 0.04^{\mathrm{c}}$ & $12.99 \pm 0.22^{c}$ \\
\hline Tinali $(T-b)$ & $5.36 \pm 0.25^{\mathrm{a}}$ & $51.03 \pm 3.15^{\mathrm{a}}$ & $7.11 \pm 0.11^{\mathrm{ab}}$ & $0.84 \pm 0.04^{\mathrm{c}}$ & $15.47 \pm 0.34^{\mathrm{d}}$ \\
\hline
\end{tabular}

Values are means of triplicate \pm standard deviations. Values in the columns bearing the different superscripts are significantly different $(p<0.05)$.

compounds and antioxidant property. This might be the reason for higher antioxidant property in green tea than black tea. Both green and black tea of Gumti variety had higher RSA and $\mathrm{IC}_{50}$ which is similar to TPC.

\subsection{Theaflavin, Thearubigin, Color, and Brightness of Black} Tea from Different Clones. Among five varieties, the highest theaflavin (TF) content of $1.07 \%$, the highest total color of $6.24 \%$, and the highest total brightness of $25.89 \%$ were found in $T-b$, while the highest thearubigin (TR) content of $9.64 \%$ was found in $C-b$ (Table 6 ). There was a significant difference in the brightness of $T-b$ and $A-b$, but in other varieties, there was no significant difference. The optimum fermentation process is indicated by the ratio of TF and TR, i.e., $1: 10$ or 1 : 12. TF : TR was sufficient for completing fermentation in all varieties except in T-b. TR content about 10 times of TF was reported, and tea with a high TF: TR has the best quality [7]. TF primarily contributes to the brightness of tea, and TR content mainly determines the color and body of tea [40], and it was reported that the brightness of black tea infusion was positively related to TF but TR was negatively related [41]. It was revealed that $A-b, C-b$, and $G-b$ had optimum fermentation time in similar conditions while $C-b$ and $T-b$ did not get sufficient time for fermentation. TF and TR also vary according to different types of tea prepared, overall oxidation of catechin to TF and TR, and also the cultivar used for the preparation of different types of tea [42].

3.5. Sensory Evaluation of Tea Type from Different Clones. Scores of sensory parameters of green tea from different clones are presented in Table 4 . Scores of dry tea appearance ranged from 7.77 in $T-g$ to 8.24 in $C-g$ which were not significantly different $(p>0.05)$. All types of tea were analyzed fresh and there were no symptoms of moldy appearance and caking of tea. Similarly, scores of aroma had also not any significant difference in all types of tea from different plant varieties. This might be due to the similar processing conditions for all types of tea. The lower value of aroma in $T 78-g$ might be due to the volatilization of the volatile compounds during fixing and drying than in other varieties. The mean sensory score for liquid color was higher in $G-g$ (13.33) than other varieties. This might be due to more efficient inactivation of enzymes than other varieties in similar conditions resulting in more green color in liquid. Liquor of green tea with a low score had a deeper hue because of the oxidation of catechins [43]. Scores for the taste of $G-g$ (30.78) are significantly superior to others. This might be due to a higher amount of polyphenols and caffeine in $G-g$. The taste of green tea is contributed by its chemical constituents like polyphenols, caffeine, amino acids, tea catechins, ascorbic acid, and nitrogen. Caffeine participates in the formation of flavoring precipitates during infusion. Hence, the caffeine content is responsible for the quality of tea [43]. Score for the infused leaf of $G-g$ (8.33) are superior was higher than others but not significantly different. Considering all these sensory parameters, the total quality score for $G-g$ was significantly superior to others (Figure 5(a)). The overall quality of tea is the combination of all parameters. Tea with more content chemical constituents has better sensory quality [44]. Scores of sensory parameters of orthodox black tea from different clones are presented in Table 5. Scores of dry tea appearance ranged from 7.4 in $T-b$ to 8.3 in $C-g$. Being freshly analyzed, symptoms of moldy appearance and caking were absent. The leaf structures (shape size and morphology) are also responsible for the difference in appearance which varies with a clonal variation. Similarly, scores of aroma ranged from 21.94 in $C$ - $b$ to 25.83 in $G-b$. This variation in aroma might be due to variations in caffeine, catechins, and amino acids which varied due to clonal variations of tea plants [45]. In the study of black tea in China, linear correlation analysis showed that concentrations of caffeine and polyphenols were correlated positively and significantly with various individual quality 


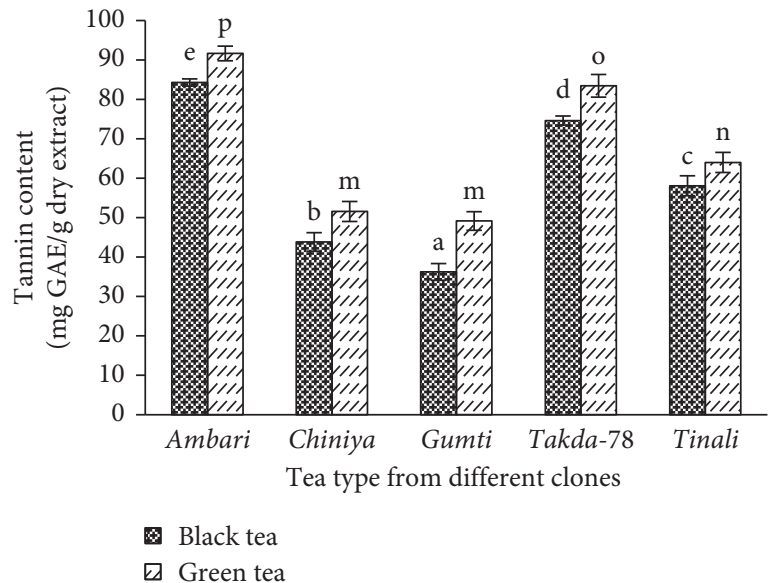

(a)

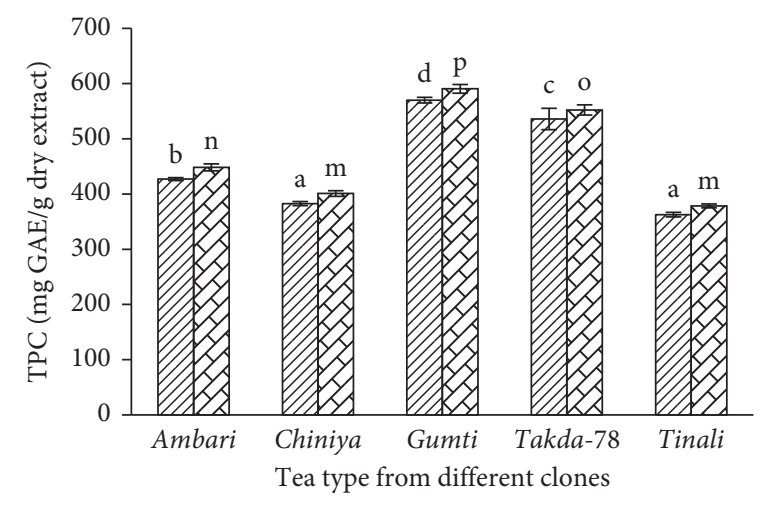

$\square$ Black tea

$\square$ Green tea

(c)

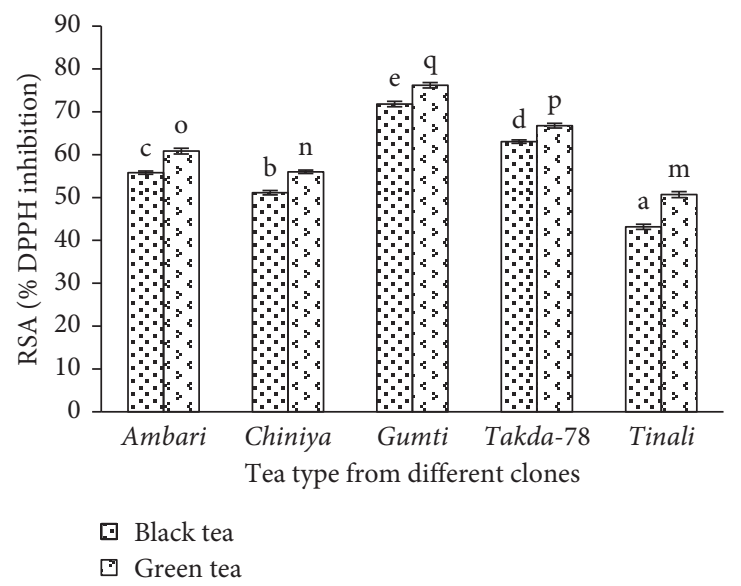

(e)

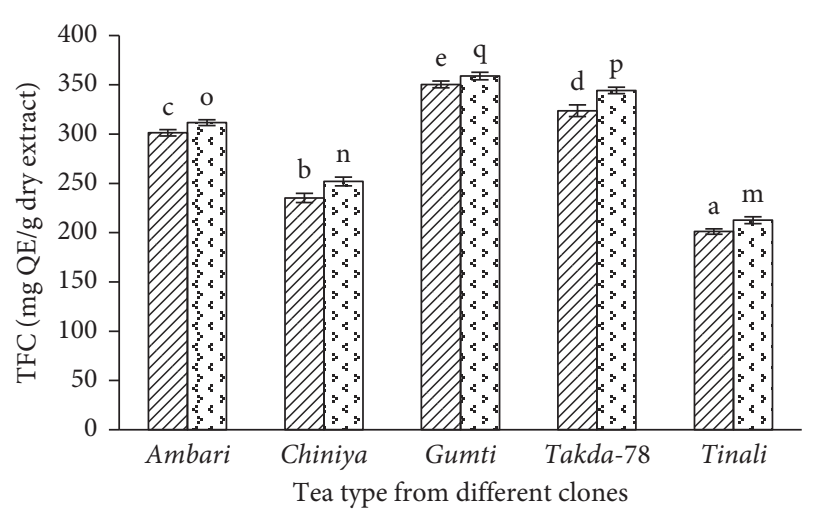

घhack tea

ㅁ Green tea

(b)

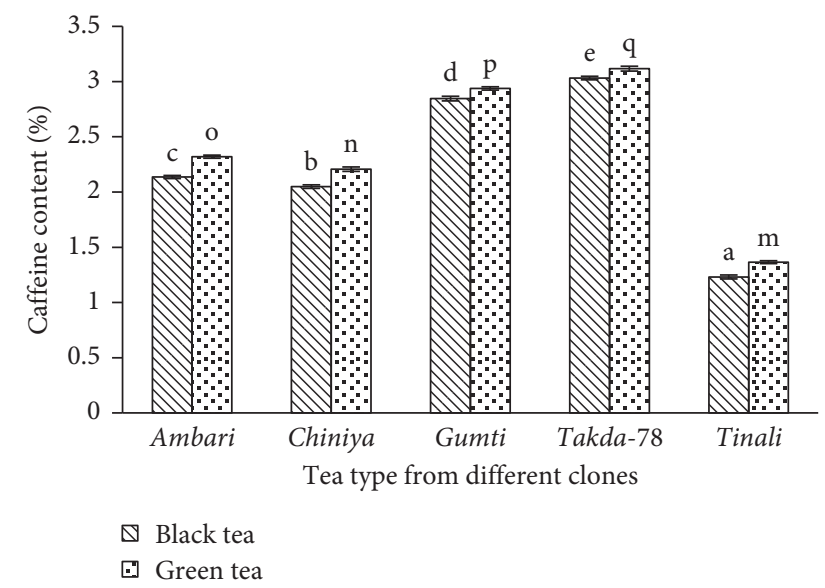

(d)

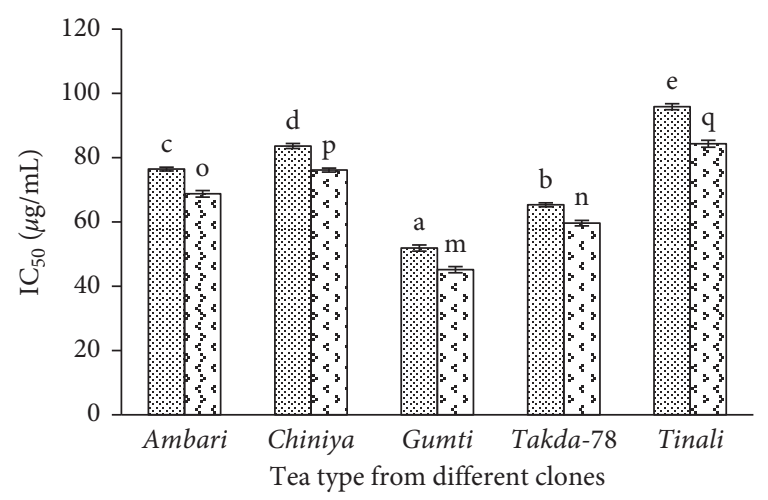

Black tea

$\square$ Green tea

(f)

Figure 4: Phytochemicals and antioxidant activity of tea types from different clones: (a) tannin content, (b) total flavonoid content, (c) total phenol content, (d) caffeine content, (e) RSA (\% DPPH inhibition), and (f) IC50. Error bars show standard deviation and error bars bearing different superscripts are different $(p<0.05)$ with one-way ANOVA, and QE, GAE, and RSA refer to quercetin equivalent, gallic acid equivalent, and radical scavenging activity, respectively.

attributes and total quality scores [22]. The mean sensory score for liquid color is higher in $G-b$ (12.92) than other varieties. This might be due to the optimum TF: TR ( $1: 9.7)$ in $G-g$ than others. The liquid color is affected by the amino acids in tea which may be oxidized by catechins, thearubigins responsible for brown color, and theaflavins for the 
TABLE 3: $t$-test for the chemical properties of green and black tea from different clones of tea plants.

\begin{tabular}{|c|c|c|c|}
\hline Variety & Chemical properties & $t$ value & $p$ value \\
\hline \multirow{6}{*}{ Ambari } & RSA (\% DPPH inhibition) & 11.36 & $<0.001^{*}$ \\
\hline & Caffeine content (\%) & 16.64 & $<0.001^{*}$ \\
\hline & Total flavonoid content (mg QE/g dry extract) & 4.09 & $0.015^{*}$ \\
\hline & $\mathrm{IC}_{50}(\mu \mathrm{g} / \mathrm{mL})$ & 11.35 & $<0.001^{*}$ \\
\hline & Total polyphenol content (mg GAE/g dry extract) & 5.36 & $0.006^{*}$ \\
\hline & Tannin content (mg GAE/g dry extract) & 6.16 & $0.004^{*}$ \\
\hline \multirow{6}{*}{ Chiniya } & RSA (\% DPPH inhibition) & 13.04 & $<0.001^{*}$ \\
\hline & Caffeine conten $(\%)$ & 10.68 & $<0.001^{*}$ \\
\hline & Total flavonoid content (mg QE/g dry extract) & 4.48 & $0.011^{*}$ \\
\hline & $\mathrm{IC}_{50}(\mu \mathrm{g} / \mathrm{mL})$ & 13.03 & $<0.001^{*}$ \\
\hline & Total polyphenol content (mg GAE/g dry extract) & 5.02 & $0.007^{*}$ \\
\hline & Tannin content (mg GAE/g dry extract) & 3.87 & $0.018^{*}$ \\
\hline \multirow{6}{*}{ Gumti } & RSA (\% DPPH inhibition) & 8.56 & $0.001^{*}$ \\
\hline & Caffeine content (\%) & 6.22 & $0.003^{*}$ \\
\hline & Total flavonoid content (mg QE/g dry extract) & 2.87 & $0.045^{*}$ \\
\hline & $\mathrm{IC}_{50}(\mu \mathrm{g} / \mathrm{mL})$ & 8.56 & $0.001^{*}$ \\
\hline & Total polyphenol content (mg GAE/g dry extract) & 3.79 & $0.019^{*}$ \\
\hline & Tannin content (mg GAE/g dry extract) & 7.06 & $0.002^{*}$ \\
\hline \multirow{6}{*}{ Takda-78 } & RSA (\% DPPH inhibition) & 9.41 & $<0.001^{*}$ \\
\hline & Caffeine content $(\%)$ & 5.47 & $0.005^{*}$ \\
\hline & Total flavonoid content (mg QE/g dry extract) & 5.28 & $0.006^{*}$ \\
\hline & $\mathrm{IC}_{50}(\mu \mathrm{g} / \mathrm{mL})$ & 9.41 & $<0.001^{*}$ \\
\hline & Total polyphenol content (mg GAE/g dry extract) & 1.04 & 0.358 \\
\hline & Tannin content (mg GAE/g dry extract) & 4.92 & $0.008^{*}$ \\
\hline \multirow{6}{*}{ Tinali } & RSA (\% DPPH inhibition) & 14.05 & $<0.001^{*}$ \\
\hline & Caffeine content (\%) & 10.46 & $<0.001^{*}$ \\
\hline & Total flavonoid content (mg QE/g dry extract) & 4.48 & $0.011^{*}$ \\
\hline & $\mathrm{IC}_{50}(\mu \mathrm{g} / \mathrm{mL})$ & 14.05 & $<0.001^{*}$ \\
\hline & Total polyphenol content (mg GAE/g dry extract) & 5 & $0.007^{*}$ \\
\hline & Tannin content (mg GAE/g dry extract) & 2.85 & $0.046^{*}$ \\
\hline
\end{tabular}

*Significant at $p<0.05, \mathrm{QE}=$ quercetin equivalent, GAE = gallic acid equivalent.

TABLE 4: Sensory attributes of green tea prepared from different clones of tea plants.

\begin{tabular}{|c|c|c|c|c|c|}
\hline Green tea from different clones & Dry tea appearance & Aroma & Liquid color & Taste & Infused leaf \\
\hline Ambari $(A-g)$ & $7.87 \pm 0.88^{\mathrm{a}}$ & $23.06 \pm 2.64^{\mathrm{a}}$ & $11.52 \pm 1.32^{\mathrm{b}}$ & $26.89 \pm 3.8^{\mathrm{ab}}$ & $7.77 \pm 1.05^{\mathrm{a}}$ \\
\hline Chiniya $(C-g)$ & $8.24 \pm 0.88^{\mathrm{a}}$ & $24.16 \pm 3.21^{\mathrm{a}}$ & $11.66 \pm 1.23^{\mathrm{b}}$ & $26.9 \pm 3.87^{\mathrm{ab}}$ & $7.59 \pm 0.79^{\mathrm{a}}$ \\
\hline Gumti (G-g) & $7.96 \pm 0.64^{\mathrm{a}}$ & $24.72 \pm 3.88^{\mathrm{a}}$ & $13.33 \pm 1.42^{\mathrm{a}}$ & $30.78 \pm 3.84^{\mathrm{b}}$ & $8.33 \pm 1.00^{\mathrm{a}}$ \\
\hline Takda-78 (T78-g) & $7.96 \pm 0.79^{\mathrm{a}}$ & $22.22 \pm 3.84^{\mathrm{a}}$ & $11.38 \pm 1.39^{\mathrm{b}}$ & $27.22 \pm 4.06^{\mathrm{ab}}$ & $7.96 \pm 0.79^{\mathrm{a}}$ \\
\hline Tinali $(T-g)$ & $7.77 \pm 1.16^{\mathrm{a}}$ & $23.33 \pm 2.01^{\mathrm{a}}$ & $11.25 \pm 1.03^{\mathrm{b}}$ & $25.60 \pm 3.50^{\mathrm{a}}$ & $7.87 \pm 0.74^{\mathrm{a}}$ \\
\hline
\end{tabular}

Values are means of triplicate \pm standard deviations. Values in the columns bearing the different superscripts are significantly different $(p<0.05)$.

TABLE 5: Sensory attributes of black tea prepared from different clones of tea plants.

\begin{tabular}{|c|c|c|c|c|c|}
\hline Black tea from different clones & Dry tea appearance & Aroma & Liquid color & Taste & Infused leaf \\
\hline Ambari $(A-b)$ & $7.59 \pm 0.43^{\mathrm{ab}}$ & $23.33 \pm 2.01^{\mathrm{ab}}$ & $11.53 \pm 1.11^{\mathrm{ab}}$ & $26.25 \pm 2.41^{\mathrm{ab}}$ & $7.68 \pm 0.57^{\mathrm{ab}}$ \\
\hline Chiniya $(C-b)$ & $7.4 \pm 0.72^{\mathrm{a}}$ & $21.94 \pm 1.71^{\mathrm{a}}$ & $12.08 \pm 1.25^{\mathrm{abc}}$ & $27.87 \pm 2.24^{\mathrm{bc}}$ & $7.96 \pm 0.64^{\mathrm{ab}}$ \\
\hline Gumti $(G-b)$ & $8.33 \pm 0.74^{\mathrm{b}}$ & $25.83 \pm 2.51^{\mathrm{c}}$ & $12.92 \pm 2.25^{\mathrm{c}}$ & $30.46 \pm 2.79^{c}$ & $8.24 \pm 1.00^{\mathrm{ab}}$ \\
\hline Takda-78 (T78-b) & $8.14 \pm 0.72^{\mathrm{ab}}$ & $24.44 \pm 2.17^{\mathrm{bc}}$ & $12.64 \pm 0.85^{\mathrm{bc}}$ & $28.19 \pm 2.93^{b c}$ & $8.51 \pm 0.86^{\mathrm{b}}$ \\
\hline Tinali $(T-b)$ & $7.4 \pm 0.7^{\mathrm{a}}$ & $23.06 \pm 2.22^{\mathrm{ab}}$ & $11.25 \pm 1.03^{\mathrm{a}}$ & $24.62 \pm 3.02^{\mathrm{a}}$ & $7.5 \pm 0.69^{\mathrm{a}}$ \\
\hline
\end{tabular}

Values are means of triplicate \pm standard deviations. Values in the columns bearing the different superscripts are significantly different $(p<0.05)$.

brightness of tea color [32]. Score of color showed positive correlation $\left(y=0.0068 x+8.9846, R^{2}=0.7907\right)$, representing more color in that tea which had more phenolic compounds. Scores for the taste of $G-b$ (30.46) was significantly superior to others. This might be due to a higher amount of polyphenols and caffeine in $G-b$. Chemical constituents like polyphenols, caffeine, amino acids, tea catechins, and ascorbic acid affect the taste of tea [43]. Score for the infused leaf of T78- $b$ (8.51) was superior to others. Score of TQS showed a positive correlation with TPC 
TABLE 6: Theaflavin (TF), thearubigin (TR), color, and brightness of black tea prepared from different clones of tea plant.

\begin{tabular}{|c|c|c|c|c|c|}
\hline Sample & TF (\%) & TR (\%) & Color (\%) & Brightness (\%) & TF:TR \\
\hline Ambari $(A-b)$ & $0.885 \pm 0.01^{\mathrm{ab}}$ & $8.29 \pm 0.27^{\mathrm{abc}}$ & $4.11 \pm 0.51^{\mathrm{a}}$ & $25.43 \pm 0.51^{\mathrm{a}}$ & $1: 9.36$ \\
\hline Chiniya $(C-b)$ & $0.748 \pm 0.04^{\mathrm{a}}$ & $9.64 \pm 0.14^{\mathrm{c}}$ & $4.42 \pm 0.63^{\mathrm{a}}$ & $25.65 \pm 0.23^{\mathrm{ab}}$ & $1: 12.8$ \\
\hline Gumti (G-b) & $0.876 \pm 0.028^{\mathrm{ab}}$ & $8.5 \pm 0.88^{\mathrm{bc}}$ & $5.13 \pm 0.37^{\mathrm{b}}$ & $25.74 \pm 0.3^{\mathrm{ab}}$ & $1: 9.71$ \\
\hline Takda-78 (T78-b) & $0.928 \pm 0.03^{\mathrm{bc}}$ & $8 \pm 0.24^{\mathrm{ab}}$ & $6.05 \pm 0.26^{c}$ & $25.79 \pm 0.44^{\mathrm{ab}}$ & $1: 8.61$ \\
\hline Tinali $(T-b)$ & $1.07 \pm 0.01^{\mathrm{c}}$ & $6.86 \pm 0.15^{\mathrm{a}}$ & $6.24 \pm 0.12^{\mathrm{c}}$ & $25.89 \pm 0.12^{\mathrm{b}}$ & $1: 6.36$ \\
\hline
\end{tabular}

Values are means of triplicate \pm standard deviations. Values in the columns bearing the different superscripts are significantly different $(p<0.05)$.

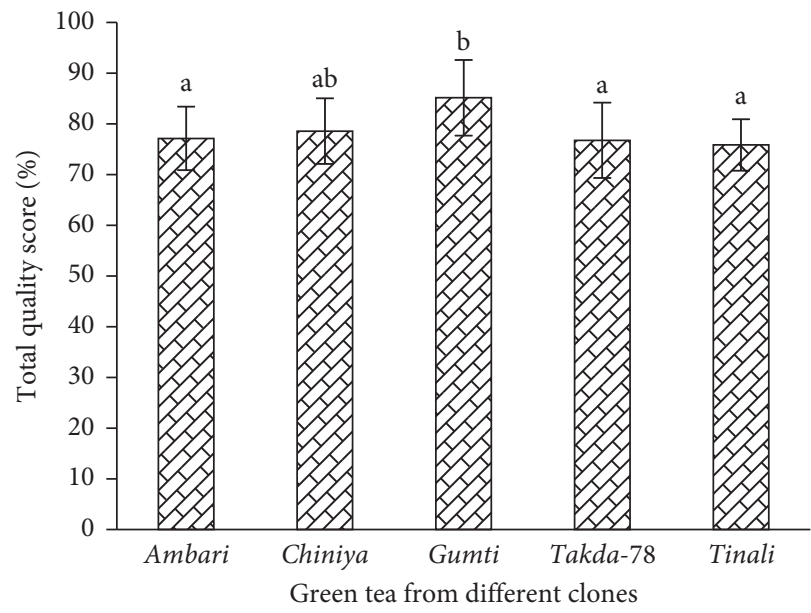

(a)

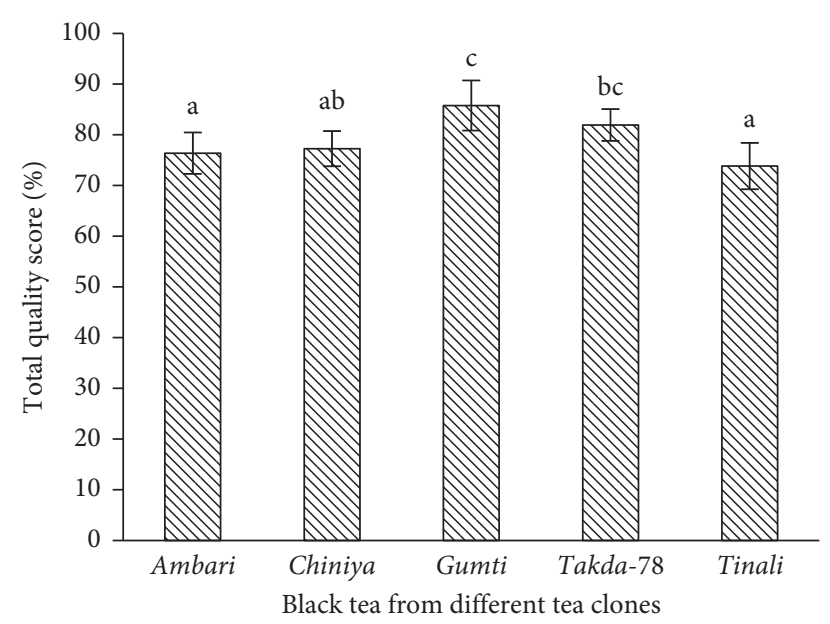

(b)

FIgURE 5: Percent total quality scores (TQS) for different varieties of (a) green tea and (b) orthodox black tea. Error bars show standard deviation and error bars bearing different superscripts are different $(p<0.05)$ with one-way ANOVA.

$\left(y=0.0494 x+56.556, \quad R^{2}=0.9168\right)$ and caffeine content $\left(y=5.9504 x+65.605, R^{2}=0.7996\right)$. Like green tea, considering all these sensory parameters, the total quality score for $G-b$ was significantly superior to others (Figure $5(b)$ ). Total polyphenols were correlated with biologically active substances (tannins, flavonoids, and antioxidant activity) and the color of black tea [38]. In our study, polyphenols were positively related to TQS, taste, and color. Thus, $G-b$ having more concentration of biologically active substances resulted in high scores for sensory attributes.

\section{Conclusions}

Tea is a widespread drink with stimulating and functional properties. In this study, among five varieties, the higher phenol content and antioxidant activity were found in the leaves of Gumti variety followed by Takda 78, Ambari, Chiniya, and Tinali, respectively. The caffeine content ranged from 2.11 to $3.56 \%$. Phytochemicals, antioxidant activity, and caffeine content were found higher in bud followed by $1^{\text {st }}$ leaf and $2^{\text {nd }}$ leaf, respectively, for all varieties of tea plants. Caffeine content was found higher in both green and orthodox tea from Takda-78 and the least in Tinali for both types of tea. Phytochemicals and antioxidant properties of green tea were significantly higher than orthodox black tea for all clones of tea plants. Gumti variety was found superior among five varieties in preparing both black and green tea for higher phytochemical, chemical, sensory quality, and antioxidant activity.

\section{Data Availability}

The data used to support the findings of this study are available from the corresponding author upon request.

\section{Conflicts of Interest}

The authors declare no conflicts of interest.

\section{References}

[1] Y. Wang, Y. Zhao, K. Andrae-Marobela, H. Okatch, and J. Xiao, "Tea polysaccharides as food antioxidants: an old woman's tale?" Food Chemistry, vol. 138, no. 2-3, pp. 1923-1927, 2013.

[2] C. Cabrera, R. Artacho, and R. Giménez, "Beneficial effects of green tea-a review," Journal of the American College of $\mathrm{Nu}$ trition, vol. 25, no. 2, pp. 79-99, 2006.

[3] P. Namita, R. Mukesh, and K. J. Vijay, "Camellia sinensis (green tea): a review," Global Journal of Pharmacology, vol. 6, pp. 52-59, 2012.

[4] Y.-S. Lin, Y.-J. Tsai, J.-S. Tsay, and J.-K. Lin, "Factors affecting the levels of tea polyphenols and caffeine in tea leaves," Journal of Agricultural and Food Chemistry, vol. 51, no. 7, pp. 1864-1873, 2003. 
[5] A. E. Thea, M. A. Lloret, L. A. Brumovsky, and M. E. Schmalko, "Differences in quality parameters between types of commercial tea from Argentina," International Journal of Food Studies, vol. 1, no. 2, 2012.

[6] S. Deb and K. R. Jolvis Pou, "A review of withering in the processing of black tea," Journal of Biosystems Engineering, vol. 41, no. 4, pp. 365-372, 2016.

[7] S. Nagalakshmi, "Tea: an appraisal of processing methods and products," in Handbook of Postharvest Technology, A. Chakraverty, A. S. Mujumdar, G. S. V. Raghavan, and H. S. Ramaswamy, Eds., Marcel Dekker, Inc., New York, NY, USA, pp. 741-778, 2003.

[8] P. Carloni, L. Tiano, L. Padella et al., "Antioxidant activity of white, green and black tea obtained from the same tea cultivar," Food Research International, vol. 53, no. 2, pp. 900-908, 2013.

[9] Y. Kim, K. L. Goodner, J.-D. Park, J. Choi, and S. T. Talcott, "Changes in antioxidant phytochemicals and volatile composition of Camellia sinensis by oxidation during tea fermentation," Food Chemistry, vol. 129, no. 4, pp. 1331-1342, 2011.

[10] K. Wang, F. Liu, Z. Liu et al., "Analysis of chemical components in oolong tea in relation to perceived quality," International Journal of Food Science \& Technology, vol. 45, no. 5, pp. 913-920, 2010.

[11] D. Pearson, "Tea and tea products," in Pearson's Chemical Analysis of Food, pp. 286-291, Churchill Livingstone, London, UK, 18 edition, 1976.

[12] AOAC, "Official methods of analysis," in Suite 500481 North Frederick Avenue Gaitherwsburg, Association of Official Analytical Chemists, Rockville, MA, USA, 18th edition, 2005.

[13] P. A. Nimal Punyasiri, B. Jeganathan, J. Dananjaya KottawaArachchi et al., "New sample preparation method for quantification of phenolic compounds of tea (Camellia sinensis L. Kuntze): a polyphenol rich plant," Journal of Analytical Methods in Chemistry, vol. 2015, Article ID 964341, 6 pages, 2015.

[14] N. A. Jaradat, F. M. Hussen, and A. Al Ali, "Preliminary phytochemical screening, quantitative estimation of total flavonoids, total phenols and antioxidant activity of Ephedra alata Decne," Journal of Materials and Environmental Science, vol. 6, no. 6, pp. 1771-1778, 2015.

[15] M. Lusia Barek, M. Hasmadi, A. Z. Zaleha, and A. B. Mohd Fadzelly, "Effect of different drying methods on phytochemicals and antioxidant properties of unfermented and fermented teas from Sabah Snake Grass (Clinacanthus nutans Lind.) leaves," International Food Research Journal, vol. 22, p. 661, 2015.

[16] K. Mythili, C. U. Reddy, D. Chamundeeswari, and P. Manna, "Determination of total phenol, alkaloid, flavonoid and tannin in different extracts of Calanthe triplicate," Journal of Pharmacognosy and Phytochemistry, vol. 2, no. 2, pp. 40-44, 2014.

[17] J. A. Vignoli, D. G. Bassoli, and M. T. Benassi, “Antioxidant activity, polyphenols, caffeine and melanoidins in soluble coffee: the influence of processing conditions and raw material," Food Chemistry, vol. 124, no. 3, pp. 863-868, 2011.

[18] A. Belay, K. Ture, M. Redi, and A. Asfaw, "Measurement of caffeine in coffee beans with UV/vis spectrometer," Food Chemistry, vol. 108, no. 1, pp. 310-315, 2008.

[19] D. Komes, D. Horžić, A. Belščak, K. Kovačević Ganič, and A. Bljak, "Determination of caffeine content in tea and maté tea by using different methods," Czech Journal of Food Sciences, vol. 27, no. 1, pp. 213-216, 2009.
[20] B. Borse and L. Jagan Mohan Rao, "Novel bio-chemical profiling of Indian black teas with reference to quality parameters," Journal of Microbial \& Biochemical Technology, vol. s14, pp. 1-16, 2012.

[21] H. Heymann, B. Machado, L. Torri, and A. L. Robinson, "How many judges should one use for sensory descriptive analysis?" Journal of Sensory Studies, vol. 27, no. 2, pp. 111-122, 2012.

[22] Y. Liang, J. Lu, L. Zhang, S. Wu, and Y. Wu, "Estimation of black tea quality by analysis of chemical composition and colour difference of tea infusions," Food Chemistry, vol. 80, no. 2, pp. 283-290, 2003.

[23] Y.-T. Hung, P.-C. Chen, R. L. C. Chen, and T.-J. Cheng, "Sequential determination of tannin and total amino acid contents in tea for taste assessment by a fluorescent flowinjection analytical system," Food Chemistry, vol. 118, no. 3, pp. 876-881, 2010.

[24] N. M. Q. Izzreen and M. A. Fadzelly, "Phytochemicals and antioxidant properties of different parts of Camellia sinensis leaves from Sabah Tea Plantation in Sabah, Malaysia," International Food Research Journal, vol. 20, no. 1, pp. 307-312, 2013.

[25] Z. Liu, M. E. Bruins, W. J. C. de Bruijn, and J.-P. Vincken, “A comparison of the phenolic composition of old and young tea leaves reveals a decrease in flavanols and phenolic acids and an increase in flavonols upon tea leaf maturation," Journal of Food Composition and Analysis, vol. 86, p. 103385, 2020.

[26] M. I. Prawira-Atmaja, H. S. Khomaini, H. Maulana, S. Harianto, and D. Rohdiana, "Changes in chlorophyll and polyphenols content in Camellia sinensis var. sinensis at different stage of leaf maturity," IOP Conference Series: Earth and Environmental Science, vol. 131, no. 1, Article ID 012010, 2018.

[27] R. Farhoosh, G. A. Golmovahhed, and M. H. H. Khodaparast, "Antioxidant activity of various extracts of old tea leaves and black tea wastes (Camellia sinensis L.)," Food Chemistry, vol. 100, no. 1, pp. 231-236, 2007.

[28] F. O. Adetuyi and T. A. Ibrahim, "Effect of fermentation time on the phenolic, flavonoid and vitamin $\mathrm{C}$ contents and antioxidant activities of okra (Abelmoschus esculentus) seeds," Nigerian Food Journal, vol. 32, no. 2, pp. 128-137, 2014.

[29] Y. Kc, R. Rai, N. Katuwal et al., "Phytochemicals, nutritional, antioxidant activity, and sensory analyses of Moringa oleifera Lam. collected from mid-hill region of Nepal," Natural Product Research, vol. 34, pp. 1-4, 2020.

[30] S. Jabeen, S. Alam, M. Saleem et al., "Withering timings affect the total free amino acids and mineral contents of tea leaves during black tea manufacturing," Arabian Journal of Chemistry, vol. 12, no. 8, pp. 2411-2417, 2019.

[31] J. M. Robinson and P. O. Owuor, "Tea: analysing and testing," in The Encyclopaedia of Food Science Food Technology and Nutrition, R. Macrae, R. Robinson, and M. Sadler, Eds., pp. 4537-4542, Academic Press, London, UK, 1993.

[32] M. E. Harbowy, D. A. Balentine, A. P. Davies, and Y. Cai, "Tea chemistry," Critical Reviews in Plant Sciences, vol. 16, no. 5, pp. 415-480, 1997.

[33] S. Jayawardhane, K. Madushanka, K. Mewan, S. Jayasinghe, N. Karunajeewa, and E. N. U. Edirisinghe, "Determination of quality characteristics in different green tea products available in Sri Lankan supermarkets," in Proceedings of the 6th symposium on plantation crop research, Colombo, Sri Lanka, November 2016.

[34] S. Sivasubramaniam and O. Talibudeen, "Effect of aluminium on growth of tea (Camellia sinensis) and its uptake of 
potassium and phosphorus," Journal of the Science of Food and Agriculture, vol. 22, no. 7, pp. 325-329, 1971.

[35] S. O. Aroyeun, "Crude fibre, water extracts, total ash, caffeine and moisture contents as diagnostic factors in evaluating green tea quality," Italian Journal of Food Science, vol. 25, no. 1, pp. 70-75, 2013.

[36] H. Orak, H. Yagar, S. Isbilir, A. Demirci, and T. Gumus, "Antioxidant and antimicrobial activities of white, green and black tea extracts," Acta Alimentaria, vol. 42, no. 3, pp. 379-389, 2013.

[37] A. V. Gadow, E. Joubert, and C. F. Hansmann, "Comparison of the antioxidant activity of rooibos tea (Aspalathus linearis) with green, oolong and black tea," Food Chemistry, vol. 60, no. 1, pp. 73-77, 1997.

[38] G. Nakov, N. Ivanova, M. Jukic, D. Koceva Komlenic, D. Daniloski, and J. Lukinac, "Perceptions of consumer for preparation and consumption of tea and analysis of biologically active compounds of black tea," Scientific Papers: Management, Economic Engineering in Agriculture \& Rural Development, vol. 20, no. 1, pp. 389-398, 2020.

[39] E. C. Chan, P. Tie, E. Soh, and Y. Law, "Antioxidant and antibacterial properties of green, black, and herbal teas of Camellia sinensis," Pharmacognosy Research, vol. 3, no. 4, p. 266, 2011.

[40] P. J. Hilton and R. T. Ellis, "Estimation of the market value of Central African tea by theaflavin analysis," Journal of the Science of Food and Agriculture, vol. 23, no. 2, pp. 227-232, 1972.

[41] F. M. Ngure, J. K. Wanyoko, S. M. Mahungu, and A. A. Shitandi, "Catechins depletion patterns in relation to theaflavin and thearubigins formation," Food Chemistry, vol. 115, no. 1, pp. 8-14, 2009.

[42] S. M. Karori, N. F. Wachira, K. J. Wanyoko, and M. R. Ngure, "Antioxidant capacity of different types of tea products," African Journal of Biotechnology, vol. 6, no. 19, pp. 2287-2296, 2007.

[43] Y. R. Liang, Q. Ye, J. Jin et al., "Chemical and instrumental assessment of green tea sensory preference," International Journal of Food Properties, vol. 11, no. 2, pp. 258-272, 2008.

[44] M. Adnan, A. Ahmad, A. Ahmed, N. Khalid, I. Hayat, and I. Ahmed, "Chemical composition and sensory evaluation of tea (Camellia sinensis) commercialized in Pakistan," Pakistan Journal of Botany, vol. 45, no. 3, pp. 901-907, 2013.

[45] S. Khokhar and S. G. M. Magnusdottir, "Total phenol, catechin, and caffeine contents of teas commonly consumed in the United Kingdom," Journal of Agricultural and Food Chemistry, vol. 50, no. 3, pp. 565-570, 2002. 